\title{
Increased Cancer Risk Associated with Radiation in Aerospace
}

Tanushri Mukherjee ${ }^{1 *}$, Soma Mukherjee ${ }^{2}$ and Rajat Dutta

${ }^{1}$ Dept of Pathology, Command Hospital, India

${ }^{2}$ Dept of Obs Gynae, AIIMS, India

${ }^{3}$ Dept of Surgery Command Hospital, India

Submission: May 04, 2017; Published: June 30, 2017

*Corresponding author: Tanushri Mukherjee, Oncopathologist, Dept of Pathology, Command Hospital, Chandimandir, Panchkula, Haryana, India, Email: tanujamukherjee@yahoo.com

\section{Abstract}

There is increased risk of malignancies in association with radiation exposure in aerospace due to UV, cosmic radiations and due to fuels. Radiation could be ionizing and non ionizing [1]. Predominantly skin malignancies are caused by non-ionizing ultraviolet radiation and UV radiation which causes DNA damage, dimerization and defective repair [2]. Leukemia occurs due to ionizing radiation. There are oncogenes implicated in human skin cancers like ras oncogenes.

Oncogenes display a positive effect on transformation, whereas tumor suppressor genes have an essentially negative effect, blocking transformation. Ionizing irradiation induces alterations within the tumor microenvironment. Radiation delivered to the tumor bed can prompt phenotypic changes in both normal stromal and cancer cells, leading to molecular and physiological alterations within the tumor microenvironment. These environmental modulations directly influence the degree of immunogenicity of the tumor microenvironment and may ultimately affect tumor responsiveness to cancer immunotherapies.

Keywords: Radiation; Melanoma; Skin cancer; Breast cancer

\section{Introduction}

Exposure of long duration to ionizing radiation causes a variety of neoplasms. The most common cases known to occur are malignant melanomas in skin, skin cancers, leukemias and breast carcinomas [1,2]. The Federal Aviation Administration (FAA) has recommended that aircrew members be exposed to no more than $20 \mathrm{mSv}$ per year for a 5 years average, with no more than $50 \mathrm{mSv}$ in a single year $[3,4]$. Radiation alters the molecular structure by causing ionization and energizing the molecule. Less energetic radiation, such as visible light, only causes excitation, not ionization, which is usually dissipated as heat with relatively little chemical damage [5-8]. Ultraviolet light is not entirely nonionizing, but produces some ionization and chemical damage. Effects of ultraviolet radiation and ionizing radiation are similar in the causation of cancer and penetrating ionizing radiation hits the molecules randomly [9-11]. Radiation causes production of free radicals by breaking the molecules and causing damage to the chromosomes and genetic rearrangements, translocations and mutations. In this way irreversible cellular damage and chromosomal derangements occur. Major damage normally results in the cell dying or being unable to reproduce with acute effects but these cells cannot cause cancer. The cells which are proliferating and in which the tumor suppressor genes are damaged, they prone to become cancerous. The latest research suggests that mutagenic events do not occur immediately after irradiation. There is phenomenon of microsatellite instability and mismatch repair in the genes which causes mutations in generations and leads to genetic predispositions to cancer. The cell will then progress through multiple stages of neoplastic transformation that may culminate into a tumor after years of incubation. Oncogenesis is due to changes in morphology of cell, uncontrolled proliferation of cells and cellular adaptions to cancer. Prolonged exposure to ultraviolet radiation from the sun can lead to melanoma and other skin cancers which are now supposed to be very common malignancies.

\section{Discussion}

Zeeb et al. [11] did not find any increased cancer mortality with radiation. The increased risk of specific malignancies has been evident predominantly in populations involved in frequent air travel such as pilots and aircrew. 
A cohort involving 10211 pilots from Nordic countries (Iceland, Sweden, Denmark, Norway and Finland) was conducted in 2003. In this study, it was found that there was increased incidence of malignant skin melanoma in pilots who flew more than 5000 block hours (hours per annum). Pukkala et al. [12] found association of melanoma with radiation exposure.

Nicholas et al. [13] identified chromosomal aberrations in peripheral lymphocytes in the blood samples of male, nonsmoker pilots based in Toronto. Fluorescent in situ Hybridization (FISH) was done and the mean aberration frequency was 3 times higher in the pilot group in contrast to the non-airline control group. Horstmann et al. [14], who concluded that space radiation does not induce a significant increase of intra-chromosomal changes after conducting FISH studies on 11 astronauts' blood lymphocytes. However the group failed to address any possibility of interchromosomal changes. Gundestrup et al. [15] have shown deletion of the long arm of chromosome 7 in aircrew members strongly associated with AML. Gundestrup et al. [16] also established causation of acute myeloid leukemia due to radiotherapy.

Breast cancer is predominantly more common in females than males; the vast majority of studies investigating the effects of ionizing radiation involve female cabin attendants and pilots. Meta-analyses have indeed shown increased incidence of breast cancer in the former. An example was that conducted by Buja et al. [17]. Bayesian hierarchal models were applied to the results of 7 published studies after standardized incidence ratios (SIRs) were estimated. Likewise similar results were portrayed by Tokomaru et al. [18]. According to Barr et al. [19], it is insufficient to draw a statistically significant conclusion pertaining to the risk of breast cancer in such a female population.

\section{Conclusion}

Age, ethnicity (genetic factors and predispositions), gender and other confounding factors facilitate carcinogenesis independent of radiation exposure. Breast cancer etiology apart from genetics, depends on numerous other factors e.g. nulliparity, smoking etc. The multivariate causes in addition to radiation exposure contribute towards causation of cancer.

\section{References}

1. Lachmansingh DA (2016) Malignancies Associated with Radiation in Aerospace Personnel-A Review of Evidence and Studies. Arch Med 8: 6.

2. Davis JR, Johnson R, Stepanek J, Fogarty JA (2008) Fundamentals of Aerospace Medicine. Lippincott Williams \& Wilkins, Philadelphia, USA.

3. Cucinotta FA, Durante M (2006) Cancer risk from exposure to galactic cosmic rays: implications for space exploration by human beings. Lancet Oncol 7(5): 431-435.
4. Lantos P, Fuller N, Bottollier-Depois J (2003) Methods for estimating radiation doses received by commercial aircrew. Aviat Space Environ Med 74(7): 746-752.

5. Goldhagen $P$ (2000) Overview of aircraft radiation exposure and recent ER-2 measurements. Health Phys 79(5): 526-544.

6. Rayman RB, Antunano MJ, Barker CO (2001) Medical guidelines for space passengers. Aviat Space and Environ Med 72(10): 948-950.

7. Rayman RB, Antunano MJ, Garber MA, Hastings JD, Illig PA, et al. (2002) Medical guidelines for space passengers-II. Aviat Space Environ Med 73(11): 1132-1134.

8. Bennett PV, Cutter NC, Sutherland BM (2007) Split-dose exposures versus dual ion exposure in human cell neoplastic transformation. Radiat Environ Biophys 46(2): 119-123.

9. Wilson JW (2000) Overview of radiation environments and human exposures. Health Phys 79(5): 470-494.

10. Cucinotta FA, Kim HY, Ren L (2006) Evaluating shielding effectiveness for reducing space radiation cancer risks. Radiation Measur 41: 11731185.

11. Zeeb H, Blettner M, Langner I, Hammer GP, Ballard TJ, et al. (2003) Mortality from cancer and other causes among airline cabin attendants in Europe: a collaborative cohort study in eight countries. Am J Epidemiol 158(1): 35-46.

12. Pukkala E, Aspholm R, Auvinen A, Eliasch H, Gundestrup M, et al. (2003) Cancer incidence among 10,211 airline pilots: a Nordic study. Aviat Space Environ Med 74(7): 699-706.

13. Nicholas JS, Butler GC, Davis S, Bryant E, Hoel DG, et al. (2003) Stable chromosome aberrations and ionizing radiation in airline pilots. Aviat Space Environ Med 74(9): 953-956.

14. Horstmann M, Durante M, Johannes C, Pieper R, Obe G (2005) Space radiation does not induce a significant increase of intrachromosomal exchanges in astronauts' lymphocytes. Radiat Environ Biophys 44(3): 219-224.

15. Gundestrup M, Klarskov Andersen M, Sveinbjornsdottir E, Rafnsson V, Storm HH, et al. (2000) Cytogenetics of myelodysplasia and acute myeloid leukaemia in aircrew and people treated with radiotherapy. Lancet 356(9248): 2158.

16. Gundestrup M, Storm HH (1999) Radiation-induced acute myeloid leukaemia and other cancers in commercial jet cockpit crew: a population-based cohort study. Lancet 354(9195): 2029-2031.

17. Buja A, Mastrangelo G, Perissinotto E, Grigoletto F, Frigo AC, et al. (2006) Cancer incidence among female flight attendants: a metaanalysis of published data. J Womens Health (Larchmt) 15(1): 98-105.

18. Tokumaru O, Haruki K, Bacal K, Katagiri T, Yamamoto T, et al. (2006) Incidence of cancer among female flight attendants: a meta-analysis. J Travel Med 13(3): 127-132.

19. Barr YR, Bacal K, Jones JA, Hamilton DR (2007) Breast cancer and spaceflight: risk and management. Aviat Space Environ Med 78(4 Suppl): A26-A37. 
(C) Commons Attribution 4.0 Licens

BY DOI: 10.19080/JTMP.2017.01.555562
Your next submission with Juniper Publishers will reach you the below assets

- Quality Editorial service

- Swift Peer Review

- Reprints availability

- E-prints Service

- Manuscript Podcast for convenient understanding

- Global attainment for your research

- Manuscript accessibility in different formats

( Pdf, E-pub, Full Text, Audio)

- Unceasing customer service

Track the below URL for one-step submission https://juniperpublishers.com/online-submission.php 